\title{
RUEDEMANN'S GASPORT CHANNEL REVISITED: INVESTIGATION OF A SILURIAN (LUDLOVIAN) KONSERVAT-LAGERSTÄTTE
}

\author{
LO DUCA, Steven, Department of Geology, Eastern Michigan University, Ypsilanti, \\ MI 48197, U.S.A.
}

In 1925 Rudolf Ruedemann described a remarkable Silurian biota dominated by noncalcified plants and animals from the Lockport Dolomite of western New York State. Ruedemann stated that the biota was confined to a single lens of interreef strata exposed at a Gasport, New York quarry; hence, he referred to the deposit as the Gasport Channel. Apart from a brief taxonomic treatment of the biota, this deposit remained largely unstudied, principally due to the destruction of the fossil site (by quarrying activity) shortly after the publication of Ruedemann's report. Recently, several new exposures of this fossil-bearing interval were discovered, prompting renewed interest in this unusual occurrence.

The stratigraphic relations of this fossil occurrence reveal that it is not a lenticular interreef channel deposit, as indicated by Ruedemann, but is instead a thin (10 $\mathrm{cm}$ on average), laterally continuous unit that overlies the bioherms. Based on the great lateral extent of this unit (over $100 \mathrm{~km}$ ), and the abundance of the noncalcified dasyclad alga Medusaegraptus mirabilis within, this interval has been termed the Medusaegraptus epibole.

The biota of the Medusaegraptus epibole is dominated by dendroid graptolites and noncalcified algae. Several well preserved worms (Protoscolex) have been recovered, as well as fragments of probable terrestrial plants. A typical Silurian shelly marine biota of brachiopods, bryozoa, corals, trilobites and crinoids is almost completely absent, although shelly material is represented by rare internal and external molds. Apparently, the Medusaegraptus epibole does not present a taphonomically biased view of a "typical" Silurian community, but instead presents a picture of an entirely different kind of Silurian association.

Based on the sedimentology and paleontology of the Medusaegraptus epibole, this unit was likely deposited in rather shallow (10-20 m), stagnant marine water. The fossil-bearing beds represent a series of tempestites with sharp, slightly erosional bases and distinct internal grading; fossil material is concentrated near the tops of these graded beds.

Other, quite similar Ludlovian Konservat-Lagerstätten from North America (basal Mississinewa Shale, Lecthaylus Shale) apparently were deposited concomitant with the Medusaegraptus epibole. Synchronous deposition of these widespread units suggests that a large-scale mechanism, such as the emplacement of dysaerobic water on the craton, may be at least partly responsible for the formation of these Silurian Konservat-Lagerstätten. 